\title{
Climate change and ontological politics in the Dutch Delta
}

\author{
Arjen Zegwaard • Arthur C. Petersen • Philippus Wester
}

Received: 7 May 2013 / Accepted: 3 September 2014 / Published online: 25 September 2014

C The Author(s) 2014. This article is published with open access at Springerlink.com

\begin{abstract}
This paper applies an ontological politics approach for studying how complexity, uncertainty, and ignorance are being dealt with in the Netherlands by looking at how knowledges are produced and incorporated in decision-making on uncertain climate change. On the basis of work done in the Netherlands, this paper shows two things in particular. First, how decision making responses historically have been subject to change under the influence of floods and how the emergence of climate change has significantly changed these floods. Second, based on the analysis of processes dealing with a blue-green algae problem in a lake, climate change not only changed decision making responses but also changed the very reality that is being enacted. Consequently, this brings an ethical dimension to the fore, related to the intrinsic tension between the growing awareness that "all is interconnected" on the one hand and the realization we cannot take all into account.
\end{abstract}

\section{Introduction}

In September 2009, the first author of this article was present at the launch of the California wing of the Delta Alliance ${ }^{1}$ in San Francisco. During this event an exploratory modeling study

\footnotetext{
${ }^{1}$ The Delta Alliance is a Netherlands-based initiative that was established for enabling knowledge sharing between various deltas, see http://www.delta-alliance.org.
}

This article is part of a special issue on "Uncertainty and Climate Change Adaptation" with guest editors Tiago Capela Lourenço, Ana Rovisco, Suraje Dessai, Richard Moss, and Arthur Petersen.

\author{
A. Zegwaard $(\bowtie) \cdot$ P. Wester \\ Water Resources Management Group, Wageningen University, Droevendaalsesteeg 3, 6708 \\ PB Wageningen, The Netherlands \\ e-mail: arjen.zegwaard@wur.nl \\ P. Wester \\ e-mail: philippus.wester@icimod.org
}

\section{A. Zegwaard · A. C. Petersen}

Institute for Environmental Studies (IVM), VU University, Amsterdam, The Netherlands

\section{A. C. Petersen}

Department of Science, Technology, Engineering and Public Policy, University College London, London, United Kingdom

P. Wester

International Centre for Integrated Mountain Development (ICIMOD), GPO Box 3226, Kathmandu, Nepal 
conducted by a Dutch consortium on the effects of climate change was presented, in which a model made for the Dutch situation was roughly adapted to the Californian situation. After this Dutch perspective on the risks facing the California Delta in the near future, one of the first questions from the audience was "What do you define as a delta?" In the discussion that followed, it turned out that the Dutch researchers had used a much broader definition of the California Delta, including the bay area, than the Californian researchers and policy makers who were present. This seemed to be more than just a confusion of tongues; it was an incompatibility of technological cultures (Shah 2008), a confusion of what constitutes a delta.

As it turns out, the ways of "knowing" deltas are multiple. This is nicely illustrated by Norgaard et al. (2009) who show how over time the ideas on what the Californian Delta are evolved. Firstly, they distinguish what they call the "early vision" of the delta as a vast and open resource, with little to no conflicts between the various interests. Then, from the 1960s onwards, the delta became more and more envisioned as a conduit for water supply, subjected to political and economic constraints. In the 1980 s, environmental constraints were "added" similar to what in the Netherlands is referred to as the "ecological turn" (Disco 2002). From 2000 onwards there was an increased recognition that little was understood about the functioning of the delta. Consequently, "[a]n awareness of uncertainty, complexity, emerging properties, and the necessity of adaptation began to coexist with a conventional, although contradictory, mandate of achieving specific goals and evaluating performance according to goal achievement" (Norgaard et al. 2009, p. 646). The evolution of these visions over time mutually constituted and recursively shaped management and political approaches. This study builds upon the idea that visions of what the delta is and its enactment not only varies over time, but also depends upon who envisions and for what reasons. Through this analysis, this article aims to understand the emergence of particular deadlocks in the governance of complex environmental problems, that is, those deadlocks that result from colliding visions on what there is that constitutes an environmental problem.

Deltas, or water bodies more generally, are objects about which knowledge is produced a posteriori. In the domain of water management studies, this has most clearly been recognized by Barnes and Alatout (2012), p. 484) "water is not a singular object of epistemology for which abstract knowledge can be produced and circulated in all times and places without interruption." What a delta is, or what a water body is, is ontology dependent. To understand how ontologies develop over time, we need to study how different ontologies interact, to study ontological politics. Ontology, in a broad sense, "is the part of philosophy concerned with what there $i$ s and what there could be" (Law 2004, p. 23). Annemarie Mol (2002) developed the idea of ontological politics in her work The Body Multiple. Following her work, and the work by John Law (2004), this study aims to show the ontological politics of climate change in the context of the Dutch Delta. This means that it tries to show how in this case climate change informs and is informed by practices of delta governance, and therewith looking at the performative and discursive character of climate change and the Delta. This means a move away from giving the object center stage in the study, but instead looking at how discourses and related practices form and transform the reality of these objects. In this article, we broadly define delta governance as the combination of problem formulations and the organization of responses to these problems. We will look at delta governance by examining what is considered, and as such what is made real, and through what mechanisms this is subject to change.

In this article, we focus on two elements of ontological politics: temporal and socio-natural dynamics. For the temporal dynamics, in line with the work by Norgaard et al. (2009) on the Californian situation, we will look at how since the early 1900s visions and approaches of dealing with the Dutch Delta have changed. For the socio-natural dynamics, in line with actor- 
network theory (e.g., Latour 2005), we will focus on mechanisms through which the delta is being scaled (Blok 2010) by looking at problem formulations, the times and spaces they take into consideration, and the publics that are sparked into being (Marres 2005).

We consider the situation in the Netherlands, and its "water culture" (Bijker 2012) as a paradigmatic case (Flyvbjerg 2006) in which climate change related uncertainties have a significant impact on the way the Dutch Delta is dealt with. This article consists of four sections. After the introduction, the second section will provide an overview of the coexistence and emergence of various ontologies in the Dutch Delta over time. The third section looks at how climate change entered the water management arena in the Netherlands and looks into the related socio-natural dynamics that surround it. The final section sums up the identified temporal and socio-natural particularities of ontological politics in the Dutch Delta and discusses the implications of what we label as an ontological lock-in.

\section{Delta ontologies over time: floods as decisive moments}

This section provides a brief review of Dutch water management literature, analyzing ontologies by looking at the histories (Norgaard et al. 2009) of science, governance, and the Dutch Delta. By applying an ontological politics lens to the literature on Dutch water management, it is striking to see the centrality of (near) flooding events as decisive moments; hence, this section focuses on four of these moments: the construction of the Afsluitdijk, the 1953 flood, the ecological turn, and the second Delta Committee.

Literature on Dutch water management extensively treats technological and societal mechanisms of dealing with water. Nearly all literature emphasizes how the Netherlands has come into being through a constant battle against water, with continuous technological innovations (van Dam 2002) and at the same time the growth of institutional capacities (Disco and van der Vleuten 2002). That the growth of institutions went hand in hand with technological capacities is shown by Kaijser (2002). TeBrake (2002) pinpoints the change from digging ditches for drainage to more codified forms of hydraulic engineering around the 12th century, enforced by the organizational strength of decentralized structures (Water Boards). Petra van Dam poses the thesis that Dutch culture is an amphibious culture with four historical strategies for dealing with floods: compartmentalization, living on (man-made) elevations (dikes, dam, or terps), daily transport over water, and the ability to evacuate cows (amphibious cows) (van Dam 2010).

Wesselink et al. (2007) highlight that there is also a down side to the rise of these institutions and technological capacities, namely the problem of a technological lock-in, which refers to the situation "where only ever-increasing efforts can keep the system operational" (Wesselink et al. 2007, pp. 192-193). Dutch attempts and confidence in its technical and institutional ability to control water culminated in the closing of the Zuiderzee (Southern Sea), by the construction of the Afsluitdijk in the 1920s/1930s. Disco and van den Ende (2003) analyze how this closure dam came about, showing that an institutional void between decentralized Water Boards and little trust in the national level Rijkswaterstaat (executive department of the Ministry of Water Affairs) with centralist ambitions, was bypassed by the installment of a special committee. Foremost, the authors show how uncertainties about the consequences of such a dam were "eliminated" by calculations by Nobel laureate Lorentz. These extremely laborious calculations can be seen as the cradle of the flourishing field of hydrological modeling, which really gathered pace around the 1930s through the work by Johannes van Veen. The final push towards closing off the Zuiderzee was given by the sea itself, in the 1916 flood, which "redefined the Zuiderzee as also a dangerous body of water" (Disco and van den Ende 2003, p. 506). 
The technological lock-in (Wesselink 2007; Wesselink et al. 2007) came into being especially after the last serious flood event in 1953 when as a response the Delta Works were constructed. Van der Vleuten and Disco see this also happening in river management in the 18th and 19th century: "While the taming of the "Water Wolf" transformed wet nature from [...] a danger to a calculable but ever-present risk, the consequent complacency has become a danger in itself' (van der Vleuten and Disco 2004, p. 292). In the 18th century, the rivers were tamed first by stabilization of the division of flow over the major branches of the rivers; in the 19th century, the rivers were "normalized" through dredging, which facilitated an increasing inland navigation function of the rivers. These river works were mainly executed by Rijkswaterstaat, which slowly grew into a "state within a state" (Disco and van der Vleuten 2002), especially through the canalization of the river Meuse (1918-1928).

The 1953 flood was the decisive moment par excellence for the Dutch. The storm surge, which led to a death toll of close to 1800 people, left a deep scar in the memories of the people living in the Southwestern Delta (see Leydesdorf 1993). The disaster also marked a radical change in the Dutch (institutional) response to flood risks, though it must be said that the plans implemented after the flood, the Delta Works, had already been drafted before the disaster took place (van der Ham 2006). After the flood, the first Delta Committee was established, which formulated a Delta Plan. The Delta Plan basically consisted of closing off all open connections to the sea, except for the Western Scheldt (connecting the harbor of Antwerp, Belgium with the North Sea) and the Nieuwe Waterweg (connecting Rotterdam to the sea), the implementation of flood risk design criteria and the raising of dikes. Delta Plan implementation has been a continuous challenge for "engineering wisdom;" first technologically (construction), later through the ecological turn. This is also reflected in the establishment of the hydrological laboratory in Delft which developed into the current Deltares. The closure of the open sea connection went rather smoothly, until the last hurdle had to be taken: the Oosterschelde.

Where the 1953 flood is generally seen as the start of large scale projects, the Oosterschelde, and the controversy surrounding its planned closure, is often seen as key in the ecological turn in Dutch water management (Disco 2002; Bijker 2005; van der Brugge et al. 2005). Wesselink et al. state: "It can be argued that the Oosterschelde dam radically changed the world of water engineering in the Netherlands" (2007, p. 196). This ecological turn resulted in a "new" way of setting up projects: "the paradigmatic breakthrough came with the presentation of a vision to combine nature development and flood protection: Plan Stork" (Wesselink et al. 2007, p. 197) in 1987. According to some authors, this turn also had its foundations in Rijkswaterstaat, seeking new legitimacy after the (near) completion of the Delta Works (van Hemert 1999; Roth and Warner 2007).

After the controversy over the Oosterschelde was settled with the construction of the Oosterschelde storm surge barrier, the attention shifted to the rivers. Especially after the high water levels in the rivers in 1993 and 1995 (for a history of river flooding in the Netherlands, see Tol and Langen 2000). "Until the (near-) floods in 1993 and 1995, the Dutch felt safe behind ever higher and stronger river dikes" (Roth and Warner 2007, p. 519). After this, the Rivers Delta Plan was formulated, which was influenced by the European Water Framework Directive (2000). Dutch water management, according to Wiering and Arts (2006), sets course to a more integrated form of water management. This was in line with international trends: "The 1990s saw a rediscovery of the positive aspects of rivers in Western Europe. Rivers had long been seen as a threat (flood risk) and treated as a dumping site for agricultural and industrial waste or an alternative transport route, requiring their channelization for navigation and flood disposal purposes" (Warner et al. 2010, p. 138). In the Netherlands, this especially materialized in the Room for the River initiative introduced in 2000, aimed at dealing with "residual risk" by means of "calamity polders." 
In 2008, the second Delta Committee presented their water and flood management plans for the Netherlands. This second Delta Committee, while it aimed to "make The Netherlands climate-proof, by reducing both the probability and the potential impacts of flooding, [...] also stated explicitly from the beginning that it would primarily focus on flood prevention, as that has proven to be the most effective strategy in the past" (van den Brink et al. 2011, p. 280). These plans were again influenced by a flooding event, this time not in the Netherlands: the Katrina flood in 2005 in New Orleans (Wesselink et al. 2007). But they were influenced even more by anticipated future flooding events as a result of the changing climate. Building on the report of the second Delta Committee, a large policy program has been established, the "Delta Program" (see e.g., Verduijn et al. 2012), headed by the Delta Commissioner.

Van der Vleuten and Disco point at the problem that in the present day "when things do go wrong - as inevitably it seems they will - the losses will be greater and in the same measure the tendency to blame the human network builders and their unruly technology instead of, as in former times, unruly nature" (2004, p. 204). In the light of knowledge controversies surrounding climate change impacts, it seems that delta management is much more a matter of dealing with uncertainties, than of building and constructing certainties. Yet it is interesting that the Dutch water management community is communicating the message internationally: "we have everything under control, our land is protected from flooding by the large engineering structures of the Delta Works (and we'd like to sell you the knowhow)" (Wesselink et al. 2007, p. 240).

In all, this brief history shows, maybe not so surprisingly, that decisions are not isolated moments in time and space, but interact with politics, science, and technologies. It is more surprising that views on the histories of floods are recursively shaped by decision making processes. Floods function as the stage for the water management community to manifest itself, they discursively shape the way in which water management is thought about and practiced. The most remarkable aspect that comes to light when looking at this history through an ontological politics lens is that this also works the other way around: the water management community constructs flood narratives, e.g., by focusing on floods elsewhere in the world (New Orleans) or even by producing floods in the future (climate change projections). In the following section, we will take a closer look at how especially the entrance of climate change has impacted ongoing processes in the Dutch Delta.

\section{Socio-natural dimensions of climate change in the Dutch Delta}

This section outlines the complexity and circumambulations of climate change adaptation in the Netherlands, by analyzing the Delta Committee (2008), the annual reports of the Delta Program (2011, 2012, 2013), background documents on adaptive delta management, and indepth interviews with the chairman of the Delta Committee and a key advisor to the Delta Program's head, the Delta Commissioner. This analysis shows that the climate change narrative has changed over time while at the same time attention for uncertainties has been small. Second, we will show how climate change has acted as a game changer in the case of the Volkerak-Zoom Lake, by showing how climate change has altered the reality, and therewith changed the issues at stake and the publics involved.

\subsection{Mainstreaming climate change}

Anticipating the increased awareness of climate change and its implications, the second Delta Committee, chaired by former minister Cees Veerman, was established by the Dutch 
government in September 2007 (Verduijn et al. 2012; Boezeman et al. 2013). The committee's task was to advise the Secretary of State on:

(a) "expected sea level rise, the interaction between that rise and the discharge in the major rivers in the Netherlands and such other developments, climatological and societal, until 21002200 as are important for the coast of the Netherlands;

(b) the consequences of such developments for the Dutch coast;

(c) possible strategies for an integral approach leading to sustainable development of the Dutch coast, based on (a) and (b); and

(d) to indicate the additional value to society of such strategies, in addition to the safety of the hinterland, in both the short and long term" (Deltacommissie 2008, p. 101).

The second Delta Committee (2008), also referred to as Veerman Committee, presented its findings Working together with water: A living land builds for its future, which contained 12 key recommendations. The first recommendation states that "The present flood protection levels of all diked areas must be raised by a factor of 10" (Deltacommissie 2008, p. 12). Later in the report, the committee explains this: "After careful consideration, it is the Committee's judgement that the flood probability in all diked areas (the amended flood protection standard) must be reduced by at least a factor of 10 below the present standards, i.e. safety levels must be increased by a factor of 10" (ibid, p. 43). The last recommendation comprised the installation of a Delta Director, the establishment of a Delta Fund and a so called Delta Program. In November 2011, the Delta Commissioner (who was installed to perform the functions originally envisaged for a "Delta Director") officially presented the national Delta Program at the first National Delta Conference. "The Delta Program is a national collaborative program of the national government, provinces, municipalities and water boards, with contributions from social organizations. The aim is to protect the Netherlands and its future generations against flooding and to safeguard a sufficient freshwater supply" (Delta Program 2011, p. 1).

The Delta Commissioner's key advisor on strategy and quality explained: "There's a significant difference between the Delta Committee and the Delta Commissioner. The committee was installed for one year. Smart people, sitting together, taking time to think about what the future of the Netherlands should be. The Delta Commissioner is about sensibleness, now it's for real, really go and look what needs to happen. Thanks [to the Delta Committee] for the inspiring words, but now it's getting serious"2. This pragmatic turn entails that where the Committee puts the year 2100-2200 as its temporal range, the Delta Program talks in a much broader sense about "future generations." Another difference is the emphasis put on "freshwater supply" by the Delta Program in its mission statement, in line with the recommendation by the Veerman committee to heighten the water level of the Netherlands' largest freshwater lake, the IJsselmeer by $1.5 \mathrm{~m}$ (Deltacommissie 2008; recommendation 11). This is probably the most controversial recommendation made by the Veerman Committee ${ }^{3}$, that proposed this measure so that "the IJsselmeer lake retains its strategic function as a fresh water reservoir for the Northern Netherlands, North Holland and, in view of the progressive salt water intrusion in the Nieuwe Waterweg, for the western Netherlands" (Deltacommissie 2008 p. 13).

When looking at the expressions of climate change and related ontic and epistemic uncertainties (Petersen 2012); it is interesting to note that over time, these have moved to the background, have become implicit. Where the Veerman Committee deliberately referred to IPCC

\footnotetext{
${ }^{2}$ Interview by A.Z. with key advisor on strategy and quality of Delta Commissioner. The Hague 5 March 2013, track 1

${ }^{3}$ See e.g., "Waterpeil IJsselmeer niet 1.5 m omhoog" in Reformatorisch Dagblad 19 September 2012
} 
reports to strengthen its arguments on the severity of climate change impacts on the Netherlands, the Delta Program makes no reference to the IPCC, but refers to the Veerman Committee instead. Which is remarkable since the Veerman Committee has been criticized for particularly highlighting worst-case scenarios (see e.g., Wesselink and Warner 2010). Veerman sees this as the responsibility of a government: "What else is a government for? It needs to consider the worst thinkable scenario. [...] After that it's a political choice to see if you say, well we're going to account for e.g. $80 \%$ [of that scenario]. [...] Look, professors and research groups need to manifest themselves, and there are always weak spots in an argumentation. That's how science works."

The Delta Program made a choice for measurement-based climate change estimations supplemented by the projections of the Royal Netherlands Meteorological Institute (KNMI). Whereas the Delta Committee intended to deliver a wake-up call, proposing radical measures based on upper limits of what might happen in terms of sea level rise and changing rainfall patterns and river discharges, the Delta Program over the past years has taken a less extreme view on climate change. In 2008, Cees Veerman wrote: "For us, the second Delta Committee, the threat is not acute, but our mandate is nevertheless urgent. There is absolutely no reason for panic, but we must be concerned for the future. If we are to be well prepared for the expected consequences of climate change, we shall have to strengthen our flood defenses and change the way our country is managed, both physically and administratively" (Deltacommissie 2008 pp. 5-7). This urgency to prepare for expected climate change did not vanish over time, but it did become less central. It became one of the elements that underlined the necessity to deal with the Delta now. This happened in two steps. First, climate change is presented as an observable, measurable fact, moving away from predictive models. This is for example explained in the 2012 Delta Program

"This Delta Program [...] is starting off with the here and now and heading towards the future, which is why, at the Delta Commissioner's suggestion, the Cabinet is basing its Delta Program on measurements and the KNMI 2006 scenarios. [...] According to observational date, the climate is changing; it has become warmer and wetter, and the sea level has risen" (Delta 2012 p. 37).

A second step is that of placing climate change alongside other forces of change. This becomes articulate in the 2013 Delta Program publication: "The number of people and the value of what needs to be protected change under the influence of economic and demographic developments. Water and the soil also change over time: the sea level rises and the soil subsides. The climate is also changing, resulting in higher temperatures and more extremes in river discharges and rainfall" (Delta 2013 p. 10).

An important factor in the mainstreaming of climate change in the water management policy making domain has been what the Delta Commissioner calls "adaptive delta management": "After all, solutions should be allowed to develop along with new insights and circumstances. That said, it is advisable to guarantee that the solutions can be implemented in a cost-effective manner when they are needed, and, in the short term, to take the first steps that are worthwhile in every scenario (no regret). In other words, adaptive delta management is not about deferring decisions or measures, but rather about taking the right steps at the right time" (Delta 2013 p. 88). With this approach, the Delta Program deliberately distances itself from its initiator, the 2008 Delta Committee. The guidance document on adaptive delta management starts with: "The Delta program takes a sensible approach. Sensible here means: interventions not based on worst-case scenarios and not assuming a fixed image for the year 2100" . Adaptive delta

\footnotetext{
${ }^{4}$ Interview by A.Z. with Cees Veerman, Groesbeek, 28 January 2013, track 1

5 Stratelligence (2012) Draft version of their "Guidance on Adaptive Delta Management"
} 
management as it is operationalized in the Delta Program provides a methodology to formulate a "preferred" strategy. To come to this preferred strategy, first, one needs to determine "tipping point and uncertainties," construct "development and adaptation pathways" and develop "favorable strategies." The selection of the "preferred" strategy from the pallet of "favorable" strategies is done through a "real options analysis" (see e.g., van Rhee et al. 2008).

What is interesting about the application of adaptive delta management is that it is presented as an economically rational methodology to formulate and select a preferred strategy, but the determination of tipping points and uncertainties are ontology dependent. The ontological basis is established purely intuitively. AZ: "how do you determine what [type of tipping points and uncertainties] you take on board and what not? What are the criteria?." RE: "There are no objective, a priori determinable [criteria]. It depends on the judgment capacity of the eight people that at that very moment [at the start-up of the process] sit together [...] we make the decision to take something into consideration based on implicit criteria. There's nothing more to it."6

In this subsection, we have highlighted how the perfomative and discursive character of climate change has changed over time. Whereas the Delta Committee framed climate change as a storm warning from the future, stressing urgency, the Delta Program approaches climate change rather as a long-term weather report, which needs to be dealt with in a sensible way. The two responses feature different repertoires, where the Delta Committee used expressions like "raising flood protection levels by a factor 10," the Delta Program rather talks about "adaptation pathways" and "favorable strategies."

\subsection{Climate change as a game changer}

Having introduced how conceptions of climate change and related uncertainties have changed in tandem with institutional setups, we will now analyze how climate change has entered a both temporally and spatially bound process dealing with a specific water quality issue in a lake. We will show how climate change has changed the nature of the problem, and therewith its "publics," the socio-natural configuration. The lake we will take a closer look at is the Volkerak-Zoom Lake (VZL), also referred to as Krammer-Volkerak-Zoom Lake. The Volkerak-Zoom Lake is an artificial lake that came into being after the completion of the Dutch Delta works in the 1980s. Before the area became a lake it was a part of the RhineMeuse estuary. As a result the Volkerak-Zoom Lake has become a freshwater body located in the center of what the Delta Program calls the Southwestern Delta. A rather radical transformation, and until recently, never really contested. This was until the early 1990s, by then in summers, the blue-green algae (Cyanobacteria) started to appear. By the early 2000s this smelly and poisonous algae was the reason for initiating studies for solving this problem (for more details on the construction of facts in the plan study process, see Zegwaard and Wester forthcoming). In this section, we will show what reality this process enacted and how over time a climate change ontology, mainstreamed in the Delta Program, marginalized the local reality.

In 2008, it appeared to be a matter of fact $^{7}$, that the freshwater Volkerak-Zoom Lake was going to be turned into a salt water lake. The reason for this was that it was the only solution for the lake's blue-green algae problem. In September $2012^{8}$, one of the key persons in the process around the Volkerak-Zoom Lake stated that the lake will remain fresh for at least the

\footnotetext{
${ }^{6}$ Interview by A.Z. with key advisor on strategy and quality of Delta Commissioner. The Hague 5 March 2013, track 4

${ }^{7}$ See e.g., de Volkskrant, 8 October 2008: Op een kier tegen te blauwalgen: Deltawerken plan van Rijkswaterstaat om een doorlaat voor zout water te maken in de Philipsdam

${ }^{8}$ Personal communication, 27 September 2012
} 
coming 10 years. Apparently, something has changed in the meantime. When we asked the same key person why the salt option was being put on hold ${ }^{9}$, the response was twofold: lack of funds and skepticism over the effectiveness of technical solutions for salt leakage problems. We would like to add another explanation for this deadlock from an ontological politics perspective: with the mainstreaming of climate change through the Veerman Committee and the Delta Program, a tension has risen between the large scale, generalist ontology related to long-term climate change projections on the one hand and the ontology of small scale, local level, and relatively short-term solutions for the blue-green algae problem on the other.

After the blue-green algae had appeared in the Volkerak-Zoom Lake in the 1990s, the responsible Secretary of State commissioned an "exploration study" for the identification of solution directions. By November 2003, the results of this study were presented. The conclusion of the exploration study was that there were eight possible solution directions, of which three were marked as preferred options. These solution directions varied from restoring the estuarine dynamics in the water body, turning the lake into a salt water lake, or maintaining the freshwater lake and flushing the algae out. After the exploration study, a plan study continued with the aim to come eventually to a decision that would solve the blue-green algae problem. This process resulted in the conclusion, in 2008, that the only way to eliminate the blue-green algae is to turn the lake into a salt water body.

At that same time, the Veerman Committee presented its recommendations and especially recommendation 8 was particularly relevant for the Volkerak-Zoom Lake:

The Krammer-Volkerak Zoommeer, the Grevelingen and possibly also the Eastern Scheldt must be re-arranged to provide temporary storage of excess water from the Rhine and Meuse when discharge to the sea is blocked by closed storm surge barriers. A salinity gradient (a natural transition between fresh and salt water) in this area is a satisfactory solution to the water quality problem and can offer new ecological opportunities. In this case an alternative fresh water supply must be provided" (Deltacommissie 2008 p. 12).

What we see that is happening here is that the Delta Committee links the lake to neighboring water bodies, namely Grevelingen and the Eastern Scheldt while creating a temporary storage of excess water that may result from expected changing discharge patterns. With this, the Volkerak-Zoom Lake became part of a new reality, introducing new problems and stretching the boundaries of the system both temporally and in terms of the socio-natural dynamics. Temporally, by introducing a 100 - to 200 -year time frame, a new socio-natural configuration was brought into being by linking the lake to the surrounding water bodies, eventually forming the Dutch Delta, with the publics that are included in these processes.

\begin{tabular}{|c|c|c|c|c|}
\hline Year & Institution & Spatiality & Problem & Temporal focus \\
\hline $2002-2003$ & $\begin{array}{l}\text { Exploration } \\
\text { Study }\end{array}$ & VZL & Blue-green algae & $15 / 40$ years \\
\hline $2004-2008$ & Plan Study & VZL & $\begin{array}{l}\text { Blue-green algae/ } \\
\text { saltwater leakage }\end{array}$ & $2015 / 2040$ \\
\hline 2008 & Veerman & The Netherlands & $\begin{array}{l}\text { Climate change } \\
\text { (especially flood risk) }\end{array}$ & $100-200$ years \\
\hline 2008-2011 & Freshwater Program & ZW-Delta & $\begin{array}{l}\text { Especially freshwater } \\
\text { provision and distribution }\end{array}$ & $\begin{array}{l}2010-2015 \text { and } \\
\text { long term }\end{array}$ \\
\hline
\end{tabular}

${ }^{9}$ Personal communication, 1 October 2012 


\begin{tabular}{|c|c|c|c|c|}
\hline 2011-2015 & Delta Program & $\begin{array}{c}\text { The Netherlands } \\
\text { (Fragmented) }\end{array}$ & $\begin{array}{l}\text { Safety (flooding and } \\
\text { freshwater) }\end{array}$ & Future generations \\
\hline 2012 & $\begin{array}{l}\text { National Structure } \\
\text { Vision }\end{array}$ & $\begin{array}{l}\text { VZL and } \\
\text { Grevelingen }\end{array}$ & Spatial organization & Short term \\
\hline
\end{tabular}

As a result of this new situation, a Freshwater Program was initiated which looked at the consequences of a saline Volkerak-Zoom Lake for the freshwater availability in the region, but also at the freshwater distribution of the entire Southwestern Delta region. When the Delta Program with all its subprograms was launched, the Southwestern Delta was incorporated as one of the six area-based subprograms, while the freshwater component of the discussion was also incorporated in the generic subprogram on freshwater and with that institutionalizing the generic climate change ontology. What happened to the Volkerak-Zoom Lake in the mean time? At the moment, a so called National Structure Vision development process has started up for the combined Volkerak-Zoom Lake and its neighbor Lake Grevelingen. In this vision, a decision is to be taken in 2015 on the re-introduction of tidal activity in the Volkerak-Zoom Lake.

In this section, we have shown how climate change and the uncertainties related to climate change have entered the water management scene in the Netherlands and how its role has changed from an apocalyptic future into a manageable change scenario for which tools are being developed. Subsequently, this section explored the consequences of this introduction for the Volkerak-Zoom Lake, showing how climate change has changed the reality in terms of spatiality, temporality, and audiences involved. Climate change has changed the specifics of the reality, and its subsequent problem, that needs policy action.

\section{Conclusion}

In this article, we have highlighted two mechanisms that we have observed through an ontological politics perspective in the Dutch attempts to deal with climate change and its related uncertainties. First, we have shown how a shift has occurred from delta governance responding to (flooding) events to delta governance constructing future events that in turn require acting upon. We have shown that throughout the 20th century the occurrence of flooding events have been essential in establishing political and societal momentum for significant changes in Delta governance, whether this be decisions to construct large dams, the formulation of a Delta Plan or changing of an attitude towards river dynamics. At the same time, while anticipating climate change, something changed about the appearance of floods, floods traveled across oceans, borrowing the floods in New Orleans as a wakeup call for Dutch politicians, and floods are imported from a produced future, sketching an apocalyptic future with regard to sea level rise and river discharges. Floods, apart from their physical character, play an important role in determining the characteristics of the object, the delta that needs to be governed.

Second, we have shown that the process of mainstreaming climate change in the Dutch Delta has caused an "expansion of reality". In the section on the socio-natural dimension of climate change in the Dutch Delta, we have analyzed what happened to the responses to a specific local problem situation in the light of the upcoming wave of climate change adaptation in the realms of water governance in the Netherlands. The ontological politics frame enabled us to show how climate change effectively penetrated the Netherlands and has irrefutably changed the nature of the reality that requires action. Climate change ontologically has 
stretched the time horizon of policy makers from a 10 to 50 years planning horizon to 100 to 200 years ahead. At the same time, the idea about the nature of risks and uncertainties has changed from locally experienced floods to floods elsewhere in the world and in times yet to come. In sum, the penetration of climate change and especially the ontic and epistemic uncertainties related to it have radically changed the playing field of water governance in the Dutch Delta. A local problem has become a cog in a machine, namely the complex Delta. As such scales of operation have grown, time has expanded, and new publics are sparked into being while others have been moved to the background (e.g., the disappearance of the bluegreen algae from the political agenda). Reality has grown.

So what are the implications of the ontological politics of climate change in the Dutch Delta? What lessons are there to be learned? The analysis presented in this paper uncovers the fundamental tension between the growing awareness that "all is interconnected" and the practical realization that it is seemingly impossible to take all into account in decision making. While expanding reality, one might grow ignorant of localized realities, like some algae in a lake.

Acknowledgments We are grateful for the financial support for the research on which this article is based from The Netherlands Organization for Scientific Research, NWO-WOTRO (Project number W 01.65.339.00). We would like to thank the interviewees for their input. We are indebted to the three anonymous reviewers for the time and effort invested in bringing more clearly to the fore the argument we want to make.

Open Access This article is distributed under the terms of the Creative Commons Attribution License which permits any use, distribution, and reproduction in any medium, provided the original author(s) and the source are credited.

\section{References}

Barnes J, Alatout S (2012) Water worlds: introduction to the special issue of social studies of science. Soc Stud Sci 42:483-488

Bijker WE (2005) The politics of water: the Oosterschelde storm surge barrier: a Dutch thing to keep the water out or not. Making things public: atmospheres of democracy / edited by Bruno Latour and Peter Weibel:512529

Bijker W (2012) Do we live in water cultures? A methodological commentary. Soc Stud Sci 42:624-627

Blok A (2010) Topologies of climate change: actor-network theory, relational-scalar analytics, and carbon-market overflows. Environ Plan D: Soc Space 28(5):896-912

Boezeman D, Vink M, Leroy P (2013) The Dutch Delta Committee as a boundary organisation. Environmental Science \& Policy

Delta Program 2011 Delta Programme: working on the delta (2011) The Hague

Delta Program 2012 Delta Programme: working on the delta (2012) The Hague

Delta Program 2013 Delta Programme (2013) The Hague

Deltacommissie (2008) Working together with water: a living land builds for its future

Disco C (2002) Remaking "nature" the ecological turn in Dutch water management. Sci Technol Hum Values 27: 206-235

Disco C, van den Ende JCMJ (2003) “Strong, invincible arguments?” Tidal models as management instruments in twentieth-century Dutch coastal engineering. Technol Cult 44:502-535

Disco C, van der Vleuten E (2002) The politics of wet system building: balancing interests in Dutch water management from the Middle Ages to the present. Knowl Technol Policy 14:21-40

Flyvbjerg B (2006) Five misunderstandings about case-study research. Qual Inq 12:219-245

Kaijser A (2002) System building from below: institutional change in Dutch water control systems. Technol Cult 43:521-548

Latour B (2005) Reassembling the social: an introduction to actor-network-theory. Oxford University Press, Oxford 
Law J (2004) After method: mess in social science. Routledge, London and New York

Leydesdorf S (1993) Het water en de herinnering. Meulenhoff, Amsterdam

Marres N (2005) No Issue, No Public. Humanities: 175

Mol A (2002) The body multiple: ontology in medical practice. Duke University Press, Durham

Norgaard RB, Kallis G, Kiparsky M (2009) Collectively engaging complex socio-ecological systems: reenvisioning science, governance, and the California Delta. Environ Sci Pol 12:644-652

Petersen AC (2012) Simulating nature: a philosophical study of computer-simulation uncertainties and their role in climate science and policy advice. CRC Press, Boca Raton, 2006

Roth D, Warner J (2007) Flood risk, uncertainty and changing river protection policy in the Netherlands: the case of "calamity polders". Tijdschr Econ Soc Geogr 98:519-525

Shah E (2008) What makes crop biotechnology find its roots? The technological culture of Bt cotton in Gujarat, India. Eur J Dev Res 20:432-447

TeBrake WH (2002) Taming the water wolf: hydraulic engineering and water management in the Netherlands during the middle ages. Technol Cult 43:475-499

Tol R, Langen A (2000) A concise history of Dutch river floods. Climatic change: 357-369

van Dam PJEM (2002) Ecological challenges, technological innovations: the modernization of sluice building in Holland, 1300-1600. Technol Cult 43:500-520

van Dam PJEM (2010) De amfibische cultuur Een visie op watersnoodrampen. In: Inaugural address. p 3-27

van den Brink M, Termeer C, Meijerink S (2011) Are Dutch water safety institutions prepared for climate change? J Water Clim Chang 2:272-287

van der Brugge R, Rotmans J, Loorbach D (2005) The transition in Dutch water management. Reg Environ Chang 5:164-176

van der Ham W (2006) Watersnoodramp van 1953 was te voorkomen. Tijdschrift voor Waterstaatsgeschiedenis 12(2003):21-31

van der Vleuten E, Disco C (2004) Water wizards: reshaping wet nature and society. Hist Technol 20:291-309

van Hemert M (1999) Ruimte voor de Ingenieur: rivierbeheer in Nederland eind jaren negentig. Kennis en Methode 23:361-387

Van Rhee C.G., Pieters M, van de Voort M.P. (2008) Real options applied to infrastructure projects: a new approach to valuing and managing risk and flexibility. International conference on infrastructure systems, Rotterdam, the Netherlands. 10-12 November 2008

Verduijn SH, Meijerink SV, Leroy P (2012) How the second Delta Committee set the agenda for climate adaptation policy: a Dutch case study on framing strategies for policy change. Water Altern 5:469-484

Warner J, Lulofs K, Bressers H (2010) The fine art of boundary spanning-making space for water in the East Netherlands. Water Altern 3:137-153

Wesselink AJ (2007) Integraal waterbeheer: de verweving van expertise en belangen. Universiteit Twente, Enschede

Wesselink A, Warner J (2010) Reframing floods: proposals and politics. Nat Cult 5:1-14

Wesselink A, Bijker W, de Vriend H (2007) Dutch dealings with the Delta. Nat Cult 2:188-209

Wiering MA, Arts BJM (2006) Discursive shifts in Dutch river management: "deep" institutional change or adaptation strategy? Hydrobiologia 565:327-338

Zegwaard A, Wester, P (Forthcoming 2014) Inside matters of facts: the re-opening of dams and debates in the Netherlands. Water Alternatives, Accepted 